\title{
Bimbingan Konseling dalam Menangani Penderita Skizofrenia Melalui Pendekatan Nilai dan Spiritual
}

\author{
Tamimatu Uzlifah \\ Universitas Islam Negeri (UIN) Sunan Kalijaga \\ liefaahmad@gmail.com
}

\begin{abstract}
The purpose of this study is to find out how to deal with schizophrenia patients using a spiritual approach. Data collection was carried out by observation, interviews and documentation at the Rehabilitation Home for Pondok Tetirah Dzikir Kuton Tegaltirto Berbah Sleman Yogyakarta. In fostering schizophrenia patients, the Institution for Rehabilitation uses a therapeutic service program which is also an integrated service program, spiritually carried out by religious methods namely Tareqat Qadariyah al-Naqsyabandiyah (TQN) Suryalaya which is therapeutic: bathing repentance, prayer, driker, khataman, manaqiban, fasting, pilgrimage, religious studies and other practices. Then physically, it is carried out with routine medical examinations, exercise, and community service. All of that is done to train the physical and spiritual health of a patient with schizophrenia. From the results of the study, it can be seen that this approach is able to handle schizophrenia patients through planting values and spirituality into their souls, although it cannot be said to be fully healed, but this development can minimize the occurrence of undesirable things and when the soul is sick the treatment starts with his soul also.
\end{abstract}

Keywords: Counseling guidance, schizophrenia, value and spiritual

\begin{abstract}
Abstrak
Tujuan penelitian ini ialah untuk mengetahui cara menangani pasien skizofrenia menggunakan pendekatan spiritual. Pengumpulan data dilakukan dengan observasi, wawancara dan dokumentasi di Panti Rehabilitasi Pondok Tetirah Dzikir Kuton Tegaltirto Berbah Sleman Yogyakarta. Dalam pembinaan pasien skizofrenia, Panti Rehabilitasi menggunakan program pelayanan terapi yang juga merupakan program layanan terpadu, secara ruhani dilakukan dengan metode religius yaitu Tareqat Qadariyah Wa Naqsyabandiyah (TQN)
\end{abstract}


Suryalaya yang dalam tareqat ini terdapat terapi: mandi taubat, shalat, dzikir, khataman, manaqiban, puasa, ziarah, kajian-kajian agama dan amalan-amalan lain. Kemudian secara jasmani, dilakukan dengan pemeriksaan medis secara rutin, olah raga, dan kerja bakti. Semua itu dilakukan guna melatih kesehatan jasmani dan ruhani seorang pasien sizofrenia. Dari hasil penelitian, dapat diketahui bahwa pendekatan ini mampu menangani pasien skizofrenia melalui penanaman nilai dan spiritual kedalam jiwanya, meski tidak dapat dikatakan sembuh seutuhnya, namun pembinaan ini dapat meminimalisir terjadinya hal-hal yang tidak diinginkan dan ketika jiwa yang sakit maka pengobatannya dimulai dari jiwanya pula.

Kata Kunci: Bimbingan konseling, skizofrenia, nilai dan spiritual

\section{Pendahuluan}

Skizofrenia adalah istilah yang cukup asing terdengar ditelinga orang awam. Penderita skizofrenia lebih sering disebut "orang gila" karena mereka sering berhalusinasi, jiwanya terganggu dan sering dianggap sebagai akibat kesurupan, guna-guna, atau kutukan. karena inilah banyak penderita skizofrenia yang dipasung dan diasingkan dari masyarakat umum setelah melalui berbagai macam pengobatan tetapi tetap tidak berhasil. Selain itu, karena dianggap akan mengganggu ketenangan masyarakat bahkan keluarganya sendiri.

Menurut Riset Kesehatan Dasar tahun 2007 bahwa prevalensi gangguan jiwa berat tertinggi terdapat di Provinsi DKI Jakarta yaitu sebesar 20,3 per 1000 penduduk. Di Indonesia sendiri, ada sekitar 1-2 \% pasien skizofrenia berdasarkan Badan Pusat Statistik pada tahun 2010. ${ }^{1}$ Sedangkan pada tahun 2013, prevalensi psikosis atau skizofrenia tertinggi adalah di DI Yogyakarta dan Aceh (masing-masing 2,7 per 1000 penduduk). ${ }^{2}$ Serta dalam jurnal lain di katakan bahwa skizofrenia merupakan gangguan jiwa yang cukup banyak ditemukan di Indonesia. Sekitar 99\% pasien yang dirawat dirumah sakit jiwa diseluruh Indonesia adalah pasien dengan skizofrenia. ${ }^{3}$

Tak sedikit dari penderita skizofrenia yang cukup beruntung untuk tinggal dirumah sakit jiwa atau semacam institusi kesehatan mental lainnya karena justru mereka menjadi target kekerasan fisik bahkan seksual dari para

${ }^{1}$ Sri Padma Sari \& Diyan Yuli Wijayanti, Keperawatan Spiritualitas Pada PasienSkizofrenia, Jurnal Ners Vol. 9, No. 1 April 2014, hal. 126.

${ }^{2}$ Lina Handayani, dkk, Faktor Resiko Kejadian Skizofrenia Di Rumah Sakit Jiwa Grhasia Daerah Istimewa Yogyakarta (DIY), Jurnal Humanitas, (Vol. 13, No. 2) ISSN: 1693-7236, hal. 136.

${ }^{3}$ Rizka Stevi Pura Wardhani dan Setia Asyanti, Penerimaan Keluarga Pasien Sjizofrenia Yang Menjalani Rawat Inap Di RSJ, Proceeding Seminar Nasional, ISSN: 978-602-71716-3-3, hal. 210. 
oknum petugas, serta sering juga dijadikan sebagai kelinci percobaan dari berbagai pengobatan alternatif yang meragukan, contohnya seperti terapi kejut listrik tanpa bius, racikan obat herbal, hingga kurungan isolasi. Banyak yang tidak memahami bahwa praktek-praktek tersebut sudah menyalahi hak asasi manusia meskipun keadaan mereka seperti itu, kemudian metode tersebut juga sudah terbukti tidak efektif untuk menangani orang-orang dengan gangguan kejiwaan.

Sebenarnya, dengan pengobatan yang tepat, penderita skizofrenia bisa disembuhkan dan dapat beraktivitas kembali seperti biasanya, melalui pendekatan spiritual misalnya. Seperti di Panti Rehabilitasi Pondok Tetirah Dzikir Kuton, Tegaltirto, Berbah, Sleman, Yogyakarta. Dimana pembinaan atau metode yang digunakan dalam membina pasien menggunakan pendekatan spiritual dengan menerapkan ilmu Tasawuf Islam yang dikenal dengan istilah Tareqat Qadariyah wa Naqsyabandiyah (TQN).

Tareqat Qadariyah Wa Naqsyabandiyah (TQN) sendiri merupakan ajaran yang digunakan sebagai metode pengajaran dan pembinaan pasien di Pesantren Suryalaya Tasikmalaya. Pondok pesantren yang didirikan oleh Syekh Abdullah Mubarak (populer dengan sebutan Abah Sepuh) pada tahun 1905 ini juga menjadi pusat pengajaran TQN paling besar pengaruhnya di Jawa dan beberapa daerah di Nusantara, bahkan penyebarannya telah meluas sampai ke luar negeri seperti Malaysia, Brunai Darussalam dan Syria. ${ }^{4}$

Pesantren ini merupakan Lembaga yang membina santri yang membutuhkan bantuan seperti pecandu NAPZA dan gangguan kejiwaan, serta penyakit lainnya. Pesantren Suryalaya berlokasi di dusun Godebag, desa Pagerageung, Kabupaten Tasikmalaya, Jawa Barat. Masa perintisan dan pertumbuhannya dalam kepemimpinan Abah Sepuh, pesantren ini mengalami banyak tantangan, baik dari pihak pemerintah kolonial, maupun pemerintah dan masyarakat pribumi. Sepeninggalnya di tahun 1956, Pesantren Suryalaya diteruskan oleh putranya, bernama Syeikh Ahmad Shohibul Wafa Tajul 'Arifin, yang kemudian lebih dikenal dengan panggilan "Abah Anom".

Dari Abah Anom bapak Tri Hardono belajar dan mendapatkan ilmu Tareqat Qadariyah wa Naqsyabandiyah (TQN) sewaktu berada di Pesantren Suryalaya Tasikmalaya dan menerapkannya di Panti Rehabilitasi yang ia dirikan setelah keluar dari Pesantren Suryalaya sebagai bentuk kepedulian dan keprihatinan mengingat semakin banyak manusia yang terpengaruh oleh nilainilai hedonisme, kompetisi, krisis ekonomi, yang mana untuk sebagian manusia,

${ }^{4}$ Sri Rijati Wardiani dan Djarlis Gunawan, Aktualisasi Budaya Terapi Air Sebagai Media Pengobatan oleh Jamaah di Pesantren Suryalaya Pagerageung Tasikmalaya, Dharmakarya: Jurnal Aplikasi Iptek, untuk. Masyarakat ISSN 1410 - 5675, Vol. 6, No. 1, Maret 2017: 33 - 39, hal. 35.

\footnotetext{
${ }^{5}$ Ibid., hal. 35.
} 
hal itu menjadi ancaman masa depan yang mengakibatkan ketidakseimbangan psikis, krisis jati diri, penyalah gunaan NAPZA serta penyakit-penyakit kronis jasmani dan rohani lainnya. ${ }^{6}$

\section{Bimbingan dan Konseling}

Bimbingan adalah proses pemberian bantuan kepada individu atau kelompok untuk memahami dan menggunakan secara luas kesempatankesempatan pendidikan, jabatan dan pribadi yang mereka miliki untuk dapat dikembangkan, dan sebagai satu bentuk bantuan yang sistemik melalui dimana individu dibantu untuk dapat memperoleh penyesuaian yang baik terhadap lingkungan dan kehidupan dimana individu tersebut berada.

Sedangkan menurut Prayitno dalam jurnal yang di tulis Hafizh, bimbingan adalah proses pemberian bantuan yang dilakukan oleh seorang ahli kepada seseorang atau beberapa orang individu, baik anak-anak, remaja, maupun dewasa, agar orang yang dibimbing dapat mengembangkan dirinya sendiri dan mandiri, dengan memanfaatkan kekuatan individu dan sarana yang ada dapat dikembangkan berdasarkan norma-norma yang berlaku. Moh. Surya juga mendefinisikan bimbingan sebagai suatu proses pemeberian bantuan yang terus menerus dan sistematis dari pembimbing kepada yang dibimbing agar tercapai kemandirian dalam pemahaman diri dan perwujudan diri, dalam mencapai tingkat perkembangan, secara optimal dan penyelesaian diri dengan lingkunganya. ${ }^{8}$

Sementara itu, Carl Rogers seorang psikolog humanis terkemuka berpandangan bahwa konseling merupakan hubungan terapi dengan klien yang bertujuan untuk melakukan perubahan self (diri) pada pihak klien, yang kemudian Rogers menegaskan pengertian konseling sebagai berikut:" The process by which structure of the self is relaxed in the safety of relationship with the therapist, and previously denied experiences are perceived and then integrated in to altered self.' Dalam hal ini Rogers lebih menekankan adanya perubahan pada diri klien sesuai dengan tujuan konseling itu sendiri, yakni untuk membantu klien.

Konseling secara terminologi berarti "memberikan arahan dan petunjuk bagi orang yang tersesat, baik arahan tersebut berupa pemikiran, dan orientasi kejiwaan, maupun etika dan penerapannya yang sesuai dan sejalan dengan jalan yang baik atau yang lebih baik darinya dan jauh dari semua bahaya. ${ }^{10}$

${ }^{6}$ http://pondoktetirahdzikir.wordpress.com/profil/diakses 26 April 2019.

${ }^{7}$ Faizah Noer Laela, Bimbingan Konseling Sosial, (Surabaya: UINSA Press. 2017), hal. 01.

${ }^{8}$ Muhammad Hafizh Ridho, Bimbingan Konseling Spiritual Terhadap Pasien Rehabilitasi Napza, (Jurnal Studia Insania, Mei 2018, hal 036-048 Vol. 6, No. 1 ISSN 2355-1011, e-ISSN 25493019 DOI: 10.18592/jsi.v6i1.1914), hal 39.

I'Ibid., hal. 05.

${ }^{10}$ Ibid., hal. 40. 


\section{Skizofrenia}

Emil Kraepelin, seorang psikiater dari Jerman yang pertama kali memperkenalkan istilah "skizofrenia" dengan menggunakan istilah demencia precox pada tahun 1896. Selanjutnya pada tahun 1911 Eugen Bleuler, psikiater dari Swiss memperkenalkan istilah "skizofrenia" yang diartikan sebagai psikosis yang perjalanannya menahun. Serangan hilang timbul, dapat berhenti atau kembali pada taraf perkembangan tertentu. ${ }^{11}$ Artinya dalam hal ini tidak bisa dipastikan kapan serangan itu muncul dan kapan akan hilang.

Skizofrenia berasal dari kata "Skizo" yang berarti retak atau pecah (Split), dan "frenia" yang berarti jiwa. Jadi, seseorang yang menderita gangguan jiwa skizofrenia adalah orang yang mengalami keretakan jiwa atau keretakan kepribadian (Spilitting of Personality). ${ }^{12}$ Sehingga perlu adanya bantuan dorongan serta dekapan dari orang-orang disekelilingnya, baik keluarganya maupun orangorang terdekat lainnya.

Dalam Jurnalnya, Lina Handayani dkk mengutip dari Departemen Kesehatan RI, bahwa skizofrenia merupakan gangguan kejiwaan dan kondisi medis yang mempengaruhi fungsi otak manusia, mempengaruhi fungsi normal kognitif, mempengaruhi emosional dan tingkah laku. ${ }^{13}$ Gangguan jiwa skizofrenia sifatnya adalah gangguan yang lebih kronis dan melemahkan dibandingkan dengan gangguan mental lainnya. ${ }^{14}$ Keberadaan penderita skizofrenia dalam masyarakat sering dianggap berbahaya, sehingga penderita skizofrenia tersebut disembunyikan bahkan dikucilkan. Tidak dibawa kedokter untuk berobat karena merasa malu bahkan ada juga yang sampai dipasung dan dikurung diruangan yang jauh dari jangkauan masyarakat. Perlakuan seperti ini sangatlah tidak berprikemanusiaan karena yang mereka butuhkan adalah dukungan dari orang sekitarnya meskipun dalam keadaan yang tidak bisa berfikir normal.

Hasmila \& Fira menjelaskan bahwa skizofrenia merupakan salah satu gangguan jiwa berat yang ditandai dengan gejala-gejala positif seperti pembicaraan yang kacau, delusi, halusinasi, gangguan kognitif dan persepsi, sedangkan gejala negatif seperti menurunnya minat dan dorongan, berkurangnya keinginan bicara dan miskinnya isi pembicaraan, afek yang datar serta terganggunya relasi personal. ${ }^{15}$ Ada juga ahli yang berpendapat bahwa terdapat

${ }^{11}$ Ayub Sani Ibrahim, Skizofrenia Spilitting Personality (Ciputat: Jelajah Nusa, 2011), hal. 02.

${ }^{12}$ Dadang Hawari, Al-Qur'an Ilmu Kedokteran Jiwa dan Kesehatan Jiwa, (Yogyakarta: PT. Dana Bhakti Prima Yasa, 2004), hal. 561.

${ }^{13}$ Ibid., hal. 136.

${ }^{14}$ Ibid.,hal. 136.

${ }^{15}$ Hasmila Sari dan Fira Fina, Dukungan Keluarga Dalam Mencegah Kekambuhan Pasien Skizofrenia Di Poliklinik Rawat Jalan RSJ Aceh (Family Support to Prevent Relaps Patient with Schizophrenia in Polyclinic of Aceh Government Mental Hospital), Idea Nursing Jurnal, (Vol. II, No. 3) ISSN:2087-2879, hal. 177. 
perbedaan esensial antara skizofrenia dengan neurotik, yaitu bahwa penderita neurotik mengalami gangguan terutama bersifat emosional, sedangkan skizofrenia terutama mengalami gangguan dalam pikiran. Pendapat ini bisa jadi benar, tetapi tidak menyeluruh. ${ }^{16}$

Skizofrenia bukanlah satu-satunya jenis gangguan psikotik dimana orang mengalami putus dari realitas tetapi ada beberapa gangguan psikotik lainnya, termasuk gangguan psikotik singkat, gangguan skizofrenifrom, gangguan skizoafektif, dan gangguan delusi. ${ }^{17} \mathrm{Jadi}$ skizofrenia hanya merupakan salah satu contoh jenis gangguan psikotik dari beberapa deretan gangguan psikotik lainnya.

Pada penderita skizofrenia ada desintegrasi pribadi dan kesehatan pribadi. Tingkah laku emosional dan intelektualnya jadi ambigious (majemuk), serta mengalami gangguan serius, dan mengalami regresi dementia total. Dia melarikan diri dari kenyataan hidup dan berdiam dalam dunia fantasinya. Tampaknya dia tidak bisa memahami lingkungannya dan responnya selalu maniacal atau kegila-gilaan. Perasaannya selalu tidak cocok, mengalami gangguan intelektual berat, sehingga pikirannya melompat-lompat tanpa arah. ${ }^{18}$ Ada beberapa ciri-ciri klinis Skizofrenia sebagai berikut:

1. Dua atau lebih dari hal-hal berikut harus muncul dalam porsi yang signifikan selama munculnya penyakit dalam waktu 1 bulan:
a. Waham/ delusi
b. Halusinasi
c. Pembicaraan yang sulit difahami (inkoheren) atau ditandai oleh asosiasi longgar
d. Perilaku tidak terorganisasi atau katatonik
e. Ciri-ciri negatif (misalnya afek datar)

2. Fungsi pada bidang-bidang seperti hubungan sosial, pekerjaan, atau perawatan diri selama perjalanan penyakit secara nyata berada dibawah tingkatan yang dapat dicapai sebelum munculnya gangguan. Apabila gangguan muncul pada masa kanak-kanak atau remaja, terdapat suatu kegagalan untuk mencapai tingkat perkembangan sosial yang diharapkan.

3. Tanda-tanda gangguan secara terus-menerus selama masa setidaknya 6 bulan. Masa 6 bulan ini harus mencakup fase aktif yang berlangsung setidaknya satu bulan dimana terjadi simtom psikotik.

\footnotetext{
${ }^{16}$ Sutardjo A. Wiramihardja, Pengantar Psikologi Abnormal, (Bandung: RefikaAditama, 2005), hal. 134.

${ }^{17}$ Jeffrey S. Nevid, dkk., Psikologi Abnormal (Jakarta: Penerbit Erlangga, 2003), edisi ke-5, jilid 2, Alih Bahasa: Tim Fakultas Psikologi Universitas Indonesia, hal. 103.

${ }^{18}$ Kartini Kartono, Psikologi Abnormal dan Abnormalitas Seksual, (Bandung: Mandar Maju, 2009), hal. 167.
} 
4. Gangguan tidak dapat diatribusikan sebagai dampak zat-zat tertentu (misalnya, penyalahgunaan zat atau pengobatan yang diresepkan) atau pada kondisi medis umum. ${ }^{19}$

\section{Pendekatan Nilai dan Spiritual}

Definisi nilai menurut para Filosof, Kirschenbum dan Rokeach dalam jurnal Ardiansyah memaparkan, Kirschenbum membedakan nilai, misalnya, membedakan nilai perilaku dalam konteks nilai antara (means values) dan nilai akhir (end values). Sedangkan, Rokeach menggunakan istilah yang berbeda dalam menyebut nilai antaranya sebagai nilai instrumental dan nilai akhir sebagai nilai terminal. ${ }^{20}$

Pada dasarnya bahwa nilai-nilai pada diri manusia dapat dilihat dari tingkah-laku. Namun, adapun nilai yang akan dikaji dalam tulisan ini adalah nilai pada tataran bimbingan spiritual, baik itu nilai yang dapat menimbulkan perilaku dekat dengan wilayah nilai etika (baik-buruk). Dalam perkembangannya terkadang nilai tak dapat dipisahkan karena nilai pada dasarnya adalah suatu keyakinan atau yang mana seseorang dapat bertindak atas dasar pilihannya. ${ }^{21}$ Dengan demikian nilai merupakan sifat yang sangat penting dan berharga dalam memanusiakan manusia.

Sementara spiritual menurut Danah Zohar, Ari Ginanjar dalam Jurnal yang ditulis Nurul Istiani dan Esti Zaduqishti, memaparkan bahwa, spiritual berasal dari bahasa latin spiritus, yang berarti sesuatu yang memberikan kehidupan atau validitas pada sebuah sistem. Menurut Ari Ginanjar, kata "spirit" bisa diartikan menjadi tiga macam yaitu moral, semangat dan sukma. Kata spiritual sendiri bisa dimaknai sebagai hal-hal yang bersifat spirit atau berkenaan dengan semangat. ${ }^{22}$ Sedangkan menurut Abdul Kadir, kata spiritual menjelaskan sifat dasar manusia yaitu sebagai makhluk yang secara mendasar dekat dengan Tuhan-nya, paling tidak selalu mencoba berjalan ke arah-Nya. Sifat ini menunjuk kepada sosok manusia yang dekat dan sadar akan diri dan Tuhan-Nya. ${ }^{23}$

Dalam hal ini peneliti memilih tempat lokasi penelitian di Panti Rehabilitasi Pondok Tetirah Dzikir Kuton, Tegaltirto, Berbah, Sleman, Yogyakarta. Tujuannya untuk mengetahui bagaimana menangani pasien

${ }^{19}$ Ibid., hal. 169.

${ }^{20}$ Ardiansyah, Upaya Bimbingan Konseling Nilai dan Spiritual Terhadap Transgender di Yogyakarta, (Counsellia: Jurnal Bimbingan dan Konseling 8 (2),71-87 November 2018, ISSN: 20883072 (Print) / 2477-5886 (Online), hal 72.

${ }^{21}$ Ibid., hal. 73.

${ }^{22}$ Nurul Istiani dan Esti Zaduqisti, Konsep Strategi Theistic Spiritual Dalam Layanan Bimbingan Konseling dan Psikoterapi Islam, (RELIGLA ISSN 1411-1632 (Paper) E-ISSN $2527-$ 5992 (Online) Vol. 20, No.2, 2017), hal 193.

${ }^{23}$ Ibid., hal. 194. 
Skizofrenia melalui pendekatan spiritual yang diterapkan oleh Pondok Tetirah Dzikir ini.

Penelitian ini menggunakan studi lapangan (field research) yang dilakukan di Panti Rehabilitasi Pondok Tetirah Dzikir Kuton Tegaltirto Berbah Sleman Yogyakarta. Penelitian yang digunakan adalah penelitian kualitatif dengan penggambaran kondisi secara faktual dan nyata yang ada di lapangan dengan menggunakan pengamatan dengan fenomena yang terjadi. ${ }^{24}$ Dan data dalam penelitian bersumber dari: pertama, hasil observasi; kedua, wawancara (Interview) dengan pemilik panti rehabilitasi ini; ketiga, dokumentasi terkait data yang ada dilingkungan panti rehabilitasi serta dari penelitian-penelitian terdahulu yang serumpun.

\section{Hasil dan Pembahasan}

\section{Selayang Pandang Panti Rehabilitasi Pondok Tetirah Dzikir}

Panti Rehabilitasi Pondok Tetirah Dzikir didirikan pada tahun 2011 dibawah naungan Yayasan Tetirah Dzikir (SK Kemenkumham No. AHU.3869.AH.01.04.Tahun 2010) namun dimulai sejak tanggal 28 Mei 2012 Panti Rehabilitasi Pondok Tetirah Dzikir berdiri secara otonom dengan Akte Notaris no 5 tanggal 28 Mei 2012, dengan Notaris Muhammad Ahus Hanafi. Panti Rehabilitasi ini dikelola langsung oleh Bapak Muhammad Tri Hardono, S.S lulusan alumni jurusan sejarah UGM. Setelah kelulusannya, Bapak Tri Hardono berguru ke Abah Anom di pondok Suryalaya Tasikmalaya. Dari Tasikmalaya pada awalnya menyembuhkan dua pasien di Kuton, Berbah. Kemudian pindah ke desa Mlangi Godean beberapa tahun, kemudian sempat pindah ke Cangkringan dan kembali ke Kuton dengan dukungan dari kakak kandungnya Ir Agus Suyanto yang juga alumnus UGM Jurusan Kehutanan. ${ }^{25}$

Kata "Tetirah" sendiri bermakna sebuah "laku" untuk beristirahat sejenak dari rutinitas. Disini akan terendapkan segala penat dan kepayahan hidup. "Dzikir" berarti "ingat". Maksudnya senantiasa ingat kepada Allah SWT, Dzat Maha Pencipta dan Pemelihara kehidupan ini. Jadi, Tetirah Dzikir adalah kontemplasi, merenung dalam rangka menemukan titik pencerahan dalam kehidupan, keluar dari berbagai problematika hidup, mengurai segala permasalahan, dengan panduan "Dzikrullah".

Pondoh Tetirah Dzikir didirikan berdasarkan visi dan misi tertentu. Visinya adalah membantu orang-orang yang bermasalah jiwanya, agar sembuh atau lebih baik kondisinya dari pada di jalanan atau di keluarga. Misi nya adalah melakukan upaya-upaya penyembuhan pasien dengan metode: didoakan, sholat

\footnotetext{
1995), hal. 11.

${ }^{24}$ Lexy J. Maleong, Metodologi Penelitian Kualitatif, (Bandung: RemajaRosdayaKarya,

${ }^{25}$ Data Profil Pondok Rehabilitasi Tetirah Dzikir tahun 2018.
} 
Bersama lima waktu dan Dzikir Bersama pada pasien semua agama dan semua suku. ${ }^{26}$

Seiring berjalannya waktu, Panti Rehabilitasi Tetirah Dzikir mendapatkan kepercayaan serta dukungan dari masyarakat serta diberikan amanah untuk menangani serta membuka pelayanan rehabilitasi sosial bagi mereka yang membutuhkan. Maka dari itu untuk mendukung kelancaran proses rehabilitasi ini sangat diharapkan bantuan dana subsidi kebutuhan dasar bagi pasien. Awalnya, Panti Rehabilitasi ini mendapatkan dana subsidi dari pemerintahan sebagaimana lembaga sosial lainnya, namun mirisnya, bantuan itu tidak lagi diberikan tanpa pemberitahuan dari awal. Hal itu disebabkan karena adanya kesalahpahaman.

Saat ini panti sangat membutuhkan tenaga kerja yang siap bertanggung jawab dalam bagian pendataan, karena disana memang Sumber Daya Manusianya sangat terbatas. Dengan sekitar 70 pasien hanya 3 orang yang membina. Tentunya pengelola utamanya sekaligus pendiri Panti Rehabilitasi Pondok Tetirah Dzikir Berbah Sleman Yogyakarta serta dibantu 2 warga setempat. ${ }^{27}$

Menurut keterangan dari Ibu Wati Sukmawati, selaku istri dari pengelola utama yakni Bapak Tri Hardono, pasien di Panti Rehabilitasi saat ini mencapai hampir 70-an dengan rincian : 50\% kasus narkoba \& psikotropika, 40\% kasus Schizophrenia/gila dan 10\% kasus depresi akibat putus cinta, konflik keluarga, gagal pilihan legislatif dll. Pasien yang paling muda yaitu anak kelas 5 Sekolah Dasar dan pasien yang paling tua berusia sekitar 80-an. Sebagian dari mereka masih dipedulikan oleh keluarganya, tapi sebagian lagi mereka diabaikan bahkan tidak pernah dijenguk sama sekali. ${ }^{28}$

Pasien di Panti Rehabilitasi ini berasal dari berbagai kalangan. Ada yang dari perguruan tinggi di Yogyakarta, ada yang dari kalangan geng-geng, bahkan ada yang pasien seorang penghafal Al-Qur'an, hafal 20 juz. Kala itu dia keluar dari pesantren dan membakar rumah, sehingga dibawa ke Panti Rehabilitasi.

\section{Metode Pembinaan}

Pada tahap awal pembinaan dimana pasien diserahkan oleh pihak keluarga atau yang bertanggung jawab, terlebih dahulu Pembina mewawancarai pihak keluarga pasien untuk mengetahui seberapa parah tingkat sakit yang dialami pasien. Selain itu, karena pasien di Pondok Tetirah Dzikir ini berasal dari semua kalangan dan bermacam sukuras dan agama. Maka ketika ada pasien yang bukan Muslim, pihak panti menjelaskan terkait metode pembinaan yang dipakai

\footnotetext{
${ }^{26}$ http://pondoktetirahdzikir.wordpress.com/profil/diakses 26 April 2019.

${ }^{27}$ Hasil Wawancara dengan ibu Wati Sukmawati selaku istri dari pengelola utama, Bapak Tri Hardono, tanggal 12 April 2019.

${ }^{28}$ Ibid.,
} 
berdasarkan asas agama Islam. Dengan demikian mereka, harus bersyahadat terlebih dahulu dan tentu saja itu sudah melalui kesepakatan dari pihak keluarganya. Sebagian dari mereka ada yang tetap pada jalan Islam, tetapi ada sebagian lagi yang ketika sembuh mereka kembali ke Agama mereka dan keluardari Islam.

Dalam proses penyembuhan pasien, kurun waktunya tidak bisa ditentukan, ada yang sebulan sudah mengalami banyak perubahan tetapi ada yang hampir satu tahun karena disesuaikan dengan tingkat keparahannya.

Metode penyadaran atau pembinaan pasien Skizofrenia merupakan satu paket kurikulum yang dilaksanakan secara ketat dan intensif dalam suatu periode tertentu. Metode pembinaan bagi pasien di Pondok Tetirah Dzikir merupakan program terpadu baik secara ruhani maupun jasmani, yaitu:

1. Secara Ruhani dilakukan dengan metode religius secara agama Islam khususnya amaliah TareqatQadariyah Wa Naqsyabandiyah (TQN) Suryalaya. Adapun terapi yang dilakukan antara lain: mandi taubat, shalat, dzikir, khataman, manaqiban, puasa, ziarah, kajian agama, dan amalan-amalan lain. Terapi ini dilakukan dengan tujuan sebagai upaya untuk membersihkan jiwa dan raga mereka dari segala bentuk kotoran jasmani dan ruhani sehingga mudah untuk menerima petunjuk ilahi.

2. Secara Jasmani, dilakukan pemeriksaan medis secara rutin, kegiatan olah raga, dan kerja ringan. Terapi tambahan berupa dialog, interaksi sosial dengan kunjungan keluarga/pengunjung, rekreasi bersama, membaca buku/ majalah.

Program pelayanan diatas tidak semuanya dilakukan setiap hari melainkan sesuai dengan jadwal berikut dalam Tabel.

\begin{tabular}{|c|c|c|c|}
\hline \multirow{2}{*}{ No. } & \multicolumn{3}{|c|}{ Nama kegiatan } \\
\hline & Harian & Mingguan & Bulanan \\
\hline 1. & Mandi Taubat & Puasa & Khataman \\
\hline 2. & Shalat & Senam & Manaqiban \\
\hline 3. & Dzikir & Olah Raga & Ziarah \\
\hline 4. & SosialisasiKe & KerjaBakti & \\
\hline 5. & $\begin{array}{l}\text { Masyarakat } \\
\text { Kajian Agama }\end{array}$ & & \\
\hline
\end{tabular}

Berdasarkan tabel diatas, berikut akan diuraikan secara rinci terkait kegiatan-kegiatan yang ada di Pondok Tetirah Dzikir ini.

\section{Mandi Taubat}

Mandi taubat TQN merupakan hal yang penting dalam proses penyadaran pasien skizofrenia, yakni mensucikan diri terlebih dahulu sebelum 
beribadah. Meskipun secara logika pikiran pasien tidak sadar tetapi proses itu tetap harus dilakukan, bahkan menurut hasil wawancara yang peneliti lakukan, didapatkan keterangan bahwasanya penderita skizofrenia lebih mudah ditangani daripada pecandu NAPZA, karena otak bagi penderita skizofrenia sudah kosong sehingga lebih mudah dalam mengarahkan nya meski untuk memulainya sulit. ${ }^{29}$

Waktu pelaksanaan mandi taubat bisa dilakukan mulai dari pukul 00:0003:00. Dan waktu yang paling baik dilakukan pada pukul 02:00 WIB selama 40 hari sebelum Tahajjud. Salah satu manfaat dari mandi taubat yaitu dapat menjadi terapi untuk menyembuhkan dan menghilangkan racun dari pasien pecandu Narkoba dan stress, bahkan bisa menyembuhkan dari penyakit gila. Sebab air yang dingin menyebabkan saraf-saraf meregang dan aliran darah lebih lancar menuju ke otak, sehingga dengan izin Allah penyakit apapun pasti bisa disembuhkan dengan mandi taubat. ${ }^{30}$ Mandi adalah bagian dari bersuci yang dalam ilmu Fiqih dikenal dengan istilah "Thaharah"." Bersuci disini mengandung arti bahwa pasien binaan diusahakan dalam keadaan suci, baik badan, pakaian, tempat tinggal, dan segala yang berhubungan dalam menempuh hidupnya yang baru seperti suci kalbu, jiwa, dhomir dan rasa. Sebenarnya, tata cara mandi taubat tidak jauh berbeda dengan mandi junub, hanya dalam niat yang dibaca yang berbeda.

Berikut ini merupakan tata cara melakukan mandi taubat Tarikat Qadariyah Wa Naqsyabandiyah (TQN) Suryalaya yang diterapkan di Pondok Tetirah Dzikir Berbah: ${ }^{32}$

1. Niat melakukan mandi taubat untuk membersihkan kotoran yang menempel di tubuh dan perbuatan-perbuatan dosa.

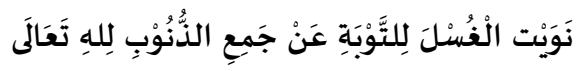

2. Bersihkan tangan dengan air yang mengucur

3. Cuci kemaluan dengan tangan kiri

4. Ambil air wudhu

5. Alirkan air dari ujung rambut sampai telapak kaki sambal membaca do'a mandi taubat sebanyak tiga kali:

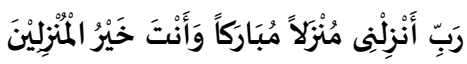

${ }^{29}$ Hasil Wawancara dengan Ibu Wati Sukmawati. tanggal 12 April 2019.

${ }^{30}$ Puji Lestari, Metode Terapi dan Rehabilitasi Korban NAPZA di Pondok Pesantren Suryalaya Tasikmalaya, SOCIA Vol. 10 No. 2, September 2013 : 100-107, hal. 105.

${ }^{31}$ Ibid., hal. 105.

${ }^{32} \mathrm{http}: / /$ bdtqns.blogspot.com/2017/07/mandi-taubat-tqn-suryalaya.html?m=1diakses 13 Mei 2019. 
Ya Tuhanku, tempatkanlah aku pada tempat yang penub berkah. Dan Engkaulah Drat yang sebaik-baiknya memberikan tempat." (QS: AlMu'minun: 29)

6. Alirkan air di bahu kanan sambil membaca doa mandi taubat. Lakukan sebanyak tiga kali.

7. Bersihkan sela-sela kaki.

\section{Shalat}

Setelah melakukan mandi taubat dilanjutkan dengan melakukan shalat, baik shalat wajib wajib, shalat sunnah taubat, shalat rawatib, shalat qiyamullail, dan shalat sunnah lain yang dilakukan pada sepertiga malam (03.00). Shalat merupakan gerakan fisik yang dilakukan dalam rangka berkomunikasi dengan Allah SWT'.33 Shalat memiliki keutamaan yang sangat besar didalam Al-Qur'an maupun As-Sunnah. Oleh karena itu, shalat adalah sebuah kebutuhan yang sangat mendasar bagi seorang hamba dan sama sekali bukan sebagai beban yang memberatkannya, bahkan shalat hakikatnya sebuah aktifitas yang sangat menyenangkan hati seorang hamba. Shalat yang dilakukan dengan baik dapat mencegah pelakunyauntuk melakukan perbuatan keji danmungkar, hal ini sesuai dengan Firman Allah dalam Al-Qur'an Surat Al-'Ankabut Ayat 45:

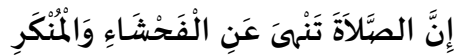

Sesunggubnya shalat itu mencegah dari (perbuatan-perbuatan) keji dan mungkar." (Al-'Ankabuut: 45)

Maka dari itu pasien diajarkan dan dibina untuk melakukan shalat yang baik supaya mereka mendapatkan hakekat kebahagiaan yang sesungguhnya serta ketenangan jiwa yang dapat membuat pasien dekat dengan Allah.

\section{Dzikir}

Dzikir merupakan bagian dari ibadah yang diperintahkan oleh Allah SW'T. Setelah mandi taubat dan dianggap mulai timbul kesadarannya, pasien kemudian melanjutkan proses selanjutnya dengan diarahkan agar mengenal, meng-Esakan dan mencintai Allah SWT. ${ }^{34}$

Dalam jurnal yang ditulis oleh Dudung Abdurrahman, bahwa dalam kitab Miftahus Shudur, Abah Anom yakni Syeikh Ahmad Shohibul Wafa Tajul 'Arifin, menyebutkan secara tidak langsung bahwa "Tareqatitu pada hakekatnya adalah dzikir", dikatakan dzikir adalah pekerjaan yang sangat utama serta

${ }^{33}$ Puji Lestari., hal. 105.

34 Ibid., 
merupakan wasilah yang dapat menghubungkan manusia dengan Tuhannya. ${ }^{35}$ Karena dzikir itu sendiri adalah sebuah aktifitas ibadah dalam umat muslim untuk mengingat Allah.

Dzikir yang dimaksud dalam Tarikat Qadariyah wa Naqsyabandiyah (TQN) adalah dzikir bermakna khas. Dzikir bermakna khas adalah hudhur alQalbi ma'a Allah (hadirnya hati kita bersama Allah). Dzikir yang dikembangkannya adalah penggabungan antara ajaran Qadariyah, yaitu berupa pengulangan dzikir jahr (Dzikir keras) atas kalimah Laa Ilaaha illaa Allah dan ajaran Naqsyabandiyah, yaitu dengan pengulangan dzikir khafi (Dzikir dalam hati) atas kata Allah. ${ }^{36}$ Pengulangan dalam kalimat dzikir berfungsi sebagai cara bagi penguatan aqidah (tauhid), sehingga diharapkan dengan mengamalkan amalan tersebut dapat memperkuat keyakinan bahwa hanya Allah tempat bergantung dan satu-satunya tempat kembali. Adapun setiap kata terutama dalam lafadz Allah yang senantiasa diucapkan dan dibisikkan dalam hati seseorang akan membuat dirinya lebih dekat dengan Allah.

\section{Khataman}

Kata khataman berasal dari kata khatama, yakhtumu, khatman, yang artinya selesai/menyelesaikan. Khataman dalam TQN adalah menyelesaikan pembacaan aurad (wirid-wirid) yang menjadi ajaran TQN pada waktu-waktu tertentu. Wirid minimal dibaca secara keseluruhan sampai khatam satu kali dalam satu minggu. ${ }^{37}$ Khataman ini dilakukan setiap selesai shalat wajib dan dzikir. Amalan khataman ini mengandung beberapa hal yaitu tawassul, membaca ayat-ayat tertentu, shalawatan dan di tutup dengan pembacaan doa khataman. Khataman merupakan penunjang utama untuk mencapai Ma'rifat dan juga berfungsi sebagai do'a yang manjur yang dipergunakan untuk memohon kepada Allah dalamurusan dunia dan akhirat.

\section{Manaqiban}

Manaqib adalah bentuk kegiatan khidmat amaliah dan ilmiah jamaah TQN. Manaqib berasal dari bahasa Arab, dari lafadz "manqobah" yang berarti kisah tentang keshalehan dan keutamaan ilmu dan amal seseorang. ${ }^{38}$ Manaqib merupakan pengamalan dari TQN yang pelaksanaannya dilakukan sekali dalam sebulan, sesuai dengan jadwal yang telah ditentukan. Manaqib memiliki susunan kegiatan sebagai berikut:

1. Pembukaan

${ }^{35}$ Dudung Abdurrahman, Reaktualisasi Pengalaman Tarekat Melalui "Lembaga Inabah" Dalam Penyembuhan Korban Narkoba, Aplikasia, Jumal Aplikasillmu-ilmu Agama, Vol. IV, No. 1 Juni 2003:14-31, hal. 21.

${ }^{36}$ Sri Rijati Wardiani dan Djarlis Gunawan, hal. 35.

${ }^{37}$ Ibid., hal. 35.

${ }^{38}$ Ibid., hal 35. 
2. Pembacaan ayat suci Al-Qur'an

3. Pembacaan Tanbih

4. Tawasul

5. Pembacaan Manaqib Syaikh Abdul Qadir Al Jaelani

6. Dakwah/ Tabliqul Islam oleh Mubaligh Pondok Pesantren

7. Pembacaan Sholawat Bani Hasyim sebanyak 3 (tiga) kali.

Seluruh rangkaian ini wajib diikuti oleh anak binaan Pondok Tetirah dzikir karena Manaqib dapat menciptakan dan mewujudkan kondisi dinamis serta tata nilai yang berharga untuk terus menerus dikembangkan oleh setiap generasi.

\section{Ziarah}

Ziarah menurut bahasa arab berasal dan akar kata zaara, yazuuru, ziyaaratan artinya berkunjung. Menurut istilah tasawuf ziarah ialah berkunjung kepada orang-orang salih, para nabi, para wali, para ulama, baik yang masih hidup maupun yang sudah wafat. ${ }^{39}$ Pada mulanya banyak perdebatan perihal ziarah dan Rasulullah sendiri pernah melarang krena dikhawatirkan ada kemusyrikan didalamnya tetapi pada akhirnya Rasulullah kembali menganjurkan karena melihat perilaku sahabat yang tidak akan menyimpng mkaa dari itu beliau percaya.

\section{Puasa}

Puasa merupakan terapi penunjang karena tidak semua diharuskan melalui kegiatan ini. Bagi mereka yang sudah baik dan sadar dianjurkan untuk melaksanakan puasa Senin dan Kamis, puasa tiga hari setiap bulan, kecuali puasa fardhu pada bulan Ramadhan seluruh anak bina diharuskan untuk melaksanakannya. ${ }^{40}$ Jadi pasien yang sudah berada dalam level baik, mereka dibina untuk melakukan puasa sunnah supaya bisa belajar sebelum akhirnya menjalankan puasa wajib yang semuanya juga wajib menjalankannya.

Disamping kegitan-kegiatan yang sangat bersifat Ilahiyat tadi, juga ada kegiatan yang menunjang kesehatan jasmani mereka supaya mereka tidak jenuh seperti sosialisasi ke masyarakat setiap hari pukul 19.30 tetapi dalam kegiatan ini hanya untuk pasien yang sudah stabil karena kalau semua diikutkan baik yang stabil ataupun masih belum dikhawatirkan malah mengganggu ketenangan masyarakat. Selain itu, juga ada kegiatan di hari minggu yaitu dilakukan kerja bakti untuk meningkatkan sikap gotong royong sesama pasien, kerja bakti juga dilakukan bersama masyarakat untuk lebih meningkatkan kedekatan dan dapat

\footnotetext{
${ }^{39}$ Ibid., hal. 35 .

${ }^{40}$ Puji Lestari., hal. 106.
} 
bersosialisasi dengan baik. Selasa pagi diselenggarakan kegiatan olah raga guna untuk lebih menyehatkan fisik para pasien, hari Rabu dilakukan senam untuk memberikan aura kegembiraan pada pasien.

Metode-metode ini memang tidak sepenuhnya bisa menyembuhkan pasien secara total tetapi setidaknya dengan mengikuti binaan yang dilakukan oleh pengurus Pondok Tetirah Dikir ini mereka sudah mengalami banyak perkembangan yang tentunya kearah yang baik dan meminimalisir adanya keresahan orang sekitar dengan keberadaannya. Sesuai informasi yang peneliti dapat dari informan, sebenarnya pasien yang mengalami gangguan kejiwaan seperti skizofrenia tidak semuanya selalu mengganggu, mereka hanya butuh keramahan dari pengunjung, ditegur atau bahkan mungkin diajak bicara meski alurnya akan nyambung atau tidak. Dengan perlakuan seperti itu mereka akan merasa senang dan merasa dihargai.

\section{Penutup}

Dibandingkan dengan Pondok Pesantren Suryalaya, Pondok Tetirah Dzikir memang belum bisa berada dititik itu. Karena Pesantren Suryalaya berdiri jauh sebelum Pondok Tetirah Dzikir ini didirikan yakni pada tahun 1905, seiring berjalannya waktu Pesantren suryalaya ini semakin dikenal masyarakat lokal maupun interlokal. Sampai pada tahun 1995, terdaftar sebanyak 24 pondok Inabah, yang tersebar di Pulau Jawa maupun di luar negeri. Di pulau Jawa ada 20 buah Inabah, 7 buah di Tasikmalaya, 4 buah di Ciamis, 3 di Bandung, dan 6 buah lainnya masirig-masing di Garut, Bogor, Kuningan, Tegal, Yogyakarta, dan Surabaya. Di luar negeri, Pondok Inabah berada di Malaysia sebanyak tiga buah, dan 1 di Singapura.

Fasilitas sarana dan pra-sarana pun di Pondok Suryalaya lebih lengkap dan lebih memadai, baik sarana pesantren dan masjid sebagai pusat pembinaan santri dan ikhwan, kompleks pendidikan formal Tsanawiyah dan Aliyah, kompleks Kampus II SLTP, SMU dan SMK, maupun kompleks Kampus I Institut Agama Islam Latifah Mubarakiyah (IAILM) dan Sekolah Tinggi Ilmu Ekonomi Latifah Mubarakiyah (STIELM), juga sarana-sarana lain seperti asrama dan Pusat Latihan Keterampilan (PLK) yang diperuntukan bagi lulusan Sekolah Menengah Kejuruan.

Kedua Pondok ini memang berbeda dari segi materi namun ajaran dan amalan yang diterapkan oleh bapak Tri Hardono adalah sama yakni sesuai dengan ilmu yang beliau dapatkan dari Pesantren Suryalaya ini. Meski Pondok Tetirah berdiri dengan segala keterbatasan tetapi hal yang peneliti kagumkan adalah Pondok itu tetap kokoh berdiri dengan segala kesederhanaannya.

Pondok Tetirah Dzikir ini memang masih tergolong baru tapi semakin lama masyarakat semakin percaya akan peran yang dilakukan oleh Pondok 
106 | Islamic Counseling: Jurnal Bimbingan dan Konseling Islam, Vol. 3, No. 2, 2019

Tetirah ini. Selain itu hal yang akan membuat pasien merasa tenteram dan damai berada di Pondok ini adalah karena lingkungannya yang jauh dari hiruk pikuk masyarakat dan lalu lintas umum sehingga pasien bisa dengan nyaman melakukan kegiatan di Pondok ini.

Tujuan yang sama dari kedua pondok ini yakni sama-sama membantu masyarakat dalam memberikan pelayanan dengan metode Tareqat Qadariyah wa Naqsyabandiyah. 


\section{Bibliografi}

A. Wiramihardja, Sutardjo.Pengantar Psikologi Abnormal. Bandung: Refika Aditama. 2005.

Abdurrahman,Dudung. (2003). Reaktualisasi Pengalaman Tareqat Melalui Lembaga Inabah Dalam Penyembuhan Korban Narkoba, Aplikasia, Jumal Aplikasi Ilmu-Ilmu Agama. Vol. IV, No. 1, Juni,:14-31.

Ardiansyah. (2018). Upaya Bimbingan Konseling Nilai dan Spiritual Terhadap Transgender di Yogyakarta.Counsellia: Jurnal Bimbingan dan Konseling. 8 (2),71-87 NovemberISSN: 2088-3072 (Print) / 24775886 (Online).

Data Profil Pondok Rehabilitasi Tetirah Dzikir tahun 2018.

Hafizh Ridho, Muhammad. (2018).Bimbingan Konseling Spiritual Terhadap Pasien Rehabilitasi Napza, Jurnal Studia Insania, Mei, hal 036-048 Vol. 6, No. 1 ISSN 2355-1011, e-ISSN 2549-3019 DOI: 10.18592/jsi.v6i1.1914.

Handayani,Lina dkk.Faktor Resiko Kejadian Skizofrenia Di Rumah Sakit Jiwa Grhasia Daerah Istimewa Yogyakarta (DIY).Jurnal Humanitas, Vol. 13, No. 2, ISSN: 1693-7236.

Hawari,Dadang.Al-Qur'an Ilmu Kedokteran Jiwa dan Kesehatan Jiwa. Yogyakarta: PT. Dana Bhakti Prima Yasa. 2004.

http://bdtqns.blogspot.com/2017/07/mandi-taubat-tqn-suryalaya.html?m=1 diakses 13 Mei 2019

http://pondoktetirahdzikir.wordpress.com/profil/ diakses 26 April 2019.

Istiani,Nurul dan Esti Zaduqisti. (2017)Konsep Strategi Theistic Spiritual Dalam Layanan Bimbingan Konseling dan Psikoterapi Islam,RELIGIA.ISSN 1411-1632 (Paper) E-ISSN 2527- 5992 (Online) Vol. 20, No.2).

J. Maleong, Lexy.Metodologi Penelitian Kualitatif. Bandung: Remaja Rosdaya Karya. 1995.

Kartono, Kartini.Psikologi Abnormal dan Abnormalitas Seksual. Bandung: Mandar Maju. 2009.

Lestari,Puji.(2013). Metode Terapi dan Rehabilitasi Korban NAPZA di Pondok Pesantren Suryalaya Tasikmalaya, SOCIA. Vol. 10, No. 2, September: 100-107.

Noer Laela, Faizah.Bimbingan Konseling Sosial, Surabaya: UINSA Press. 2017.

Padma Sari, Sri \& Diyan Yuli Wijayanti. (2014.). Keperawatan Spiritualitas Pada Pasien Skizofrenia.Jurnal Ners. Vol. 9, No. 1 April. 
Rijati Wardiani,Sri dan Djarlis Gunawan. (2017). Aktualisasi Budaya Terapi Air Sebagai Media Pengobatan oleh Jamaah di Pesantren Suryalaya Pagerageung Tasikmalaya,Dharmakarya: Jurnal Aplikasi Ipteks untuk Masyarakat ISSN 1410 - 5675, Vol. 6, No. 1, Maret,: 33 - 39.

S. Nevid, Jeffrey dkk. Psikologi Abnormal. Jakarta: Penerbit Erlangga. 2003. edisi ke-5, jilid 2, Alih Bahasa: Tim Fakultas Psikologi Universitas Indonesia.

Sani Ibrahim, Ayub.Skizofrenia Spilitting Personality. Ciputat: Jelajah Nusa. 2011.

Sari,Hasmila dan Fira Fina.Dukungan Keluarga Dalam Mencegah Kekambuhan Pasien Skizofrenia Di Poliklinik Rawat Jalan RSJ Aceh (Family Support to Prevent Relaps Patient with Schizophrenia in Polyclinic of Aceh Government Mental Hospital),"Idea Nursing Jurnal. Vol. II, No. 3, ISSN:2087-2879.

Stevi Pura Wardhani, Rizka dan Setia Asyanti.Penerimaan Keluarga Pasien Skizofrenia Yang Menjalani Rawat Inap Di RSJ, Proceeding Seminar Nasional, ISSN: 978-602-71716-3-3. 